\title{
Implementation of Problem-Project Based Learning Model in Elementary School
}

\author{
Ilham Aji Asmara Dewa ${ }^{1}$, Ristiana Dyah Purwandari ${ }^{2}$ \\ \{ilhamajiasmara@gmail.com ${ }^{1}$, ristianadyah@yahoo.com²
}

\begin{abstract}
Elementary School 1 Kertanegara $^{1}$, Elementary School Teacher Study Program, Universitas Muhammadiyah Purwokerto ${ }^{2}$
\end{abstract}

\begin{abstract}
This research is motivated by low scientific attitudes and mastery of student concepts in the process of learning Natural Sciences in elementary school.The purpose of this research is to find out the differences in scientific attitudes and mastery of student concepts as a result of the implementation of the Problem-Project Based Learning model.This study used a kuasi experimental method with non-equivalent design (Pretest and Posttest) Control Design, The subject of the study was grade V students at Public Elementary School 1 Kaliori, as many as 34 students.The instruments used are the scale of scientific attitudes and the test of concept mastery.Data analysis in this study using Independent Sample t-test.The findings in this study were every indicator of scientific attitudes and mastery of concepts for the experimental group getting a greater average $\mathrm{N}$-gain from the control group.The average $\mathrm{N}$-gain for each indicator in the experimental group is still in the moderate and low category, while the control group is relatively low.The results showed (1) there is a scientific attitude between students who obtain learning with problem-project based learning and non Problem-Project Based Learning models, average $\mathrm{N}$-gain for Problem-Project Based Learning 0,41 or $41 \%$ and non Problem-Project Based Learning 0,37 or $38 \%$.(2) There is an increase in concept mastery between students who obtain learning with Problem-Project Based Learning and non Problem-Project Based Learning models, on average N-gain for Problem-Project Based Learning 0,32 or 32\% and non-Problem-Project Based Learning 0,19 or 19\%.(3) Every stage in Problem-Project Based Learning can facilitate scientific attitude and mastery of the concept of grade $V$ students in elementary school where the research is conducted.
\end{abstract}

Keywords: Scientific Attitudes, Mastery of Concepts, Problem-Project Based Learning

\section{Introduction}

Academic year 2020/2021 applied at the level of Public Elementary School 1 Kaliori is learning using the 2013 Curriculum or thematic learning.Curriculum learning patterns 2013 require students to be scientific in the learning process.Students as learning subjects must play an active role in learning, teachers only act as mentors, motivators and facilitators.A good learning process is expected to improve the understanding of student concept mastery.Mastery of concepts is the ability of students to identify and analyze concepts in theory and application ${ }^{[1]}$.Mastery of concepts can help students in solving problems that exist in everyday life and to combine the knowledge that students have.Real concepts must be mastered properly by students as this will affect the level of mastery of the concept that will be possessed $^{[2]}$.

Students' achievement in understanding a learning concept is one of the indicators of success.Bloom's learning framework reveals that mastery of concepts is part of knowledge, where knowledge is the first dimension of educational and cognitive outcomes ${ }^{[3]}$. Categories in the mastery dimension of the concept include, C1 (remember), C2 (understand), C3 (apply), 
C4 (analyze), C5 (evaluate), and C6 (create).Mastery of the concept of students that has been obtained can foster the creativity of learners in solving a problem.Based on the description above, researchers define concept mastery is a student's cognitive ability on the theme of 5 ecosystems of grade $\mathrm{V}$ elementary school that can be measured through categories $\mathrm{C} 1$ to $\mathrm{C} 4$ (knowing to analyze).

Based on the results of pre-research obtained through document data, observations and interviews with grade V teachers at Public Elementary School 1 Kaliori, that there are several problems encountered in Public Elementary School 1 Kaliori.In the teaching and learning process is still centered on the teacher, students only listen to the material explanation and then do the task given by the teacher.The learning process is more dominant using lecture methods, so that student involvement in learning is still lacking.Teaching and learning activities have not used innovative and fun learning models that can increase students' interest and learning outcomes.In addition, the utilization of learning media is not optimal because at the time of learning teachers only use text media as a learning medium so that students' enthusiasm in following the learning is still lacking which ultimately impacts the student's learning outcomes that are not maximal.

Facts in the field showed the results of learning midterm assessment of Natural Sciences subjects semester I students grade V Public Elementary School 1 Kaliori showed that most students have not reached the Minimum CompletedNess Criteria that have been set which is 65.The average Natural Sciences grade V a. is 62,30 and the Average V b class score is 63,00 .In accordance with the reality above the learning of natural sciences, there needs to be innovations in innovative learning models and can foster students' ability to be scientific, activate students in the learning process, and increase the effectiveness of ongoing learning so that students get maximum mastery of concepts and are expected to improve the ability of students scientifically so as to improve the learning outcomes of Natural Sciences.

Scientific attitude is one of the factors that can influence the learning process and greatly influence the success of mastery of the concept that will be obtained by students.Scientific attitudes should be developed in the study of Natural Sciences ${ }^{[4]}$.Scientific attitude was closely related to achievement in science ${ }^{[5]}$.Students' scientific attitudes are basically no different from other skills (cognitive, social, process and psychomotor) ${ }^{[6]}$.A positive scientific attitude makes the learning process fun, so that students can master the concept of Natural Sciences well. The indicators of scientific attitudes in this study: 1) Curiosity, 2) Critical thinking, 3) Honesty, 4) Working openly and 5) Discipline ${ }^{[7]}$, 6) Curiosity, 7) Respect for data/facts, 8) Critical thinking attitudes, 9) Attitudes of discovery and creativity and 10) Open-mindedness and cooperation $^{[8]}$.

Based on some of the indicators above have a slight difference but in fact the same.Researchers will select and focus indicators of scientific attitudes a) curiosity b) critical thinking attitudes c) honest d) attitudes of discovery and creativity that will be developed in the student's scientific attitude questionnaire.Every learning should develop a positive scientific attitude so that students can master the concept and feel that the conditions in learning have a flexible, pleasant, and inspiring atmosphere.Such an atmosphere occurs in learning so that students' learning activities will be full of meaning and the activities and creativity carried out by students can be achieved optimally ${ }^{[9]}$.

Researchers want to use a model that allows students to be scientific and master concepts during the Natural Science learning process through real and factual problems. One of the learning models in curriculum 2013 is a combination of problem based learning and project based learning models.Problem-Project Based Learning research has been conducted and combined ${ }^{[10]}$, there are several steps in Problem-Project Based Learning learning, namely: (a) 
Forming groups; (b) Orientation of participants on the issue; (c) Tutoril I (building processes in groups); (d) Learn independently; (e) Tutorial II, at this stage the learning aims to bridge the processing of skills; (f) Project and presentation tasks.It is hoped that the Problem-Project Based Learning learning model can actively encourage students to come up with ideas to solve problems and realistic solutions and be directly involved in the process of problem definition, problem solving, decision return, and other investigative creativity.Problem-Project Based Learning learning model is expected as one of the innovative development models that can be applied to the learning of Natural Sciences in Elementary School and can improve scientific attitudes and mastery of student concepts.

\section{Method}

Research methods are a scientific way to obtain data with specific purposes and uses ${ }^{[11]}$. The selection of research methods becomes a way to carry out research on the condition that the selected method must be relevant to the topic to be researched.The research method used in this research is pseudo experimental research method or quasi-experimental so the research must be done conditionally while paying attention to the factors that affect the validity of the research results. The experimental quarle had an experimental group (A) and a control group (B) dission without random placement procedures ${ }^{[12]}$. In both groups, both pretest and posttest were conducted but only the experimental group (A) was treated.This explains that the group taken in the study was based on the researchers' objectives. The pretest and posttest instruments of scientific attitude scale and mastery of concepts in this research are as follows:

Table 1 Instruments pretest and posttest scientific attitudes

\begin{tabular}{|c|c|c|c|}
\hline Number & Indicator & Statement & $\begin{array}{l}\text { Question } \\
\text { Number }\end{array}$ \\
\hline \multirow[t]{6}{*}{1.} & \multirow[t]{6}{*}{$\begin{array}{l}\text { Curious } \\
\text { attitude }\end{array}$} & $\begin{array}{l}\text { I like to ask the teacher if there is material that I don't understand. } \\
(+)\end{array}$ & 1 \\
\hline & & $\begin{array}{l}\text { If the teacher asks questions about the lesson, I prefer to be quiet. } \\
(-)\end{array}$ & 2 \\
\hline & & $\begin{array}{l}\text { I find out what happened in the neighborhood by asking } \\
\text { questions. }(+)\end{array}$ & 3 \\
\hline & & $\begin{array}{l}\text { I am indifferent (or not paying attention) when the teacher } \\
\text { explains when the science lesson is taking place (-) }\end{array}$ & 4 \\
\hline & & $\begin{array}{l}\text { The science material being taught made me want to continue } \\
\text { studying Science }(+)\end{array}$ & 5 \\
\hline & & Science lessons are a waste of time (-) & 6 \\
\hline \multirow[t]{6}{*}{2.} & \multirow{6}{*}{$\begin{array}{l}\text { Critical } \\
\text { thinking } \\
\text { attitude }\end{array}$} & Suitability of the problem with the material $(+)$ & 7 \\
\hline & & Critical thinking questions make students feel challenged (+) & 8 \\
\hline & & The suitability of the time given to the number of questions $(+)$ & 9 \\
\hline & & The science teaching aids used do not support science learning (-) & 10 \\
\hline & & $\begin{array}{l}\text { The science material being taught makes me lazy to learn Science } \\
(-)\end{array}$ & 11 \\
\hline & & $\begin{array}{l}\text { The way the teacher teaches science makes me lazy to learn } \\
\text { science (-) }\end{array}$ & 12 \\
\hline
\end{tabular}


3. Honest When working on the practice questions given by the teacher I am confident in my own answers (+)

When doing science questions or assignments given by the teacher I feel bored (-)

When doing test questions, I saw a friend's work (-)

I dare to represent the group answering questions from the teacher $(+)$

I want all subjects taught like science lessons (+)

Science lessons are a waste of time (-)

4. Attitude of I am passionate about displaying learning outcomes (+)

discovery and creativity

Science subject matter can be applied in life (+)

I like to discuss in completing science assignments (+)

I am not confident in conveying ideas and ideas (-)

I can't understand the material smoothly (-)

I can't answer the question smoothly (-)

Note: positive statement (+), negative statement (-)

Table 2 Instrument pretest and posttest mastery concepts

\begin{tabular}{|c|c|c|c|c|c|}
\hline \multirow{2}{*}{ Indicator } & \multicolumn{4}{|c|}{ Concept Mastery Aspects } & \multirow{2}{*}{$\begin{array}{l}\text { Question } \\
\text { Number }\end{array}$} \\
\hline & $\mathrm{C} 1$ & $\mathrm{C} 2$ & $\mathrm{C} 3$ & $\mathrm{C} 4$ & \\
\hline Students can recall the concept of Ecosystem $(\mathrm{C} 1)$ & $\sqrt{ }$ & & & & 1 \\
\hline Students can define ecosystem (C1) & $\sqrt{ }$ & & & & 2 \\
\hline Students can Group the type of parser (C2) & & $\sqrt{ }$ & & & 3 \\
\hline $\begin{array}{l}\text { Students can give examples of plants producing food } \\
\text { (C2) }\end{array}$ & & $\sqrt{ }$ & & & 4 \\
\hline $\begin{array}{l}\text { Students can implement the concept of } \\
\text { the food chain }(\mathrm{C} 3)\end{array}$ & & & $\sqrt{ }$ & & 5 \\
\hline Students can apply forest conservation methods (C3) & & & $\sqrt{ }$ & & 6 \\
\hline $\begin{array}{l}\text { Students can distinguish the right actions in } \\
\text { the use of natural resources (C4) }\end{array}$ & & & & $\sqrt{ }$ & 7 \\
\hline $\begin{array}{l}\text { Students can find the function of animal breeding } \\
\text { related to the preservation of natural resources (C4) }\end{array}$ & & & & $\sqrt{ }$ & 8 \\
\hline
\end{tabular}

Note: remember $(\mathrm{C} 1)$, understand (C2), apply (C3), analyze (C4) 


\section{Results and Discussion}

The findings and discussion of this research were obtained from quantitative data based on the results of scientific attitude scale and student concept mastery test.The assessment is based on the findings of pretest and posttest results during the research process. The collected research data was taken from 34 students of Public Elementary School 1 Kaliori subdistrict karanganyar purbalingga district consisting of two groups of experiments and controls, totaling 17 students in the experimental group as well as 17 students from the control group.The learning process was carried out in the experimental group using Problem-Project Based Learning learning while in the control group using non Problem-Project Based Learning model learning.

\subsection{Implementation of Learning with Problem-Project Based Learning Model that facilitates Scientific Attitude and Mastery of Student Concepts}

The following are described learning activities conducted in experimental groups that use problem-project based learning models. The prerequisite material in this learning is ecosystem and the core material is the food chain in the ecosystem. The learning process starts from an aperception activity to explore students' initial knowledge with questions and answers about students' understanding of the food chain. The learner's early knowledge plays an important role as he learns about things that have something to do with what is already known ${ }^{[13]}$.

\subsubsection{Forming groups}

The first step of the Problem-Project Based Learning model is fundamental determination, at this stage the student activity starts from the formation of the nearest house group because the learning conditions in the school have not been possible to be held, then researchers and teachers teach in the student's home and divide the students into several groups.The findings of this activity are when students start face-to-face learning at the student's home with the teacher after a few months of not entering the school the learning activities are diverted by online learning. The initial learning process activities at this stage are very enthusiastic students.

\subsubsection{Student orientation to the problem}

The next stage of the Problem-Project Based Learning model is the orientation of students on the problem. Student activities at this stage see video shows about the food chain and conduct questions and answers about students' understanding of the process of food chain occurrence and human activities that affect it.In this activity, learning is directed at students active in expressing an idea by formulating problems and explaining the causative factors of the problems in the vidio impressions about the food chain. The findings in this activity are when students observe the video of learning, interest, motivation, curiosity of students quite well.Because almost all students at this stage seem enthusiastic to listen and see the video show. The enthusiasm comes because for students learning by seeing video shows is very interesting. The conclusion was obtained from interviews with class teachers and student representatives.In this case the learning media in the form of video shows is very instrumental to develop scientific attitudes to increase students' curiosity and motivate students to learn. The 
use of media in general can cause passion for learning, more direct interaction between students with learning resources and overcoming the limitations of space, time, energy and senses $^{[14]}$.

\subsubsection{Tutorial I (building processes in groups)}

The next stage of the Problem-Project Based Learning model is tutorial I (building processes in groups), after a question and answer about video shows that students are introduced to problems related to the benefits of the food chain around.The problem is obtained from reading a text about the food chain and looking at the environmental conditions around the school where the students live.The purpose of reading activities in this stage is that students are expected to be able to ask questions about food chain problems, be able to formulate problems related to food chain problems and be able to identify the causes of food chain processes in the surrounding environment.The interrelationship of reading with critical scientific attitudes, reading ability is related to the ability to transfer understanding and solve problems faced $^{[15]}$.

At this stage it was found that students still feel ashamed in conveying ideas in formulating problems or expressing questions. These findings, as reported in previous research, are in the starting stages with the essential questions questions still arise from teachers, and students are not used to applying questions that can be used as the beginning of learning ${ }^{[16]}$. Therefore, teachers guide them by giving direction or assistance by means of learning support to students in practicing expressing ideas and formulating a problem.

\subsubsection{Self-learning through inquiry}

The next stage of the Problem-Project Based Learning model is self-learning through investigation, at this stage the student experience in getting used to solving problems plays a role in identifying the causative factors and fostering an attitude of discovery and creativity to the environment.Childhood experiences have a strong influence on future developments ${ }^{[17]}$. In the sense that if a good understanding and experience of the environment is introduced to students from an early age it will have a positive impact and will shape the attitude of discovery and creativity in the future.

Direct student involvement in ecosystem conditions in the surrounding environment has a positive effect and the planting of students' scientific attitudes towards the surrounding environment.Students are introduced to how the food chain is growing and efforts to maintain its sustainability.Direct interaction in learning can play an important role in shaping a collaborative learning environment, having a positive effect on enabling students to trigger reflective thinking and make learning more flexible in relation to time and place ${ }^{[18]}$.The next activity is for students to have discussions with their groups to develop problem solving steps on the object of their observations.Discussion activities play a role in facilitating students to exchange opinions with their friends in determining questions and choices to be decided ${ }^{[19]}$.

\subsubsection{Tutorial II (bridging skills processing)}

The next stage of the Problem-Project Based Learning model is tutorial II (bridging skills processing), at this stage students conduct discussions to determine which projects will be made based on student observations and source search results (reading books and browsing the internet) about the food chain.This is like the results of research that explains decision-making 
skills using authentic or real problems in the field and small group discussions in decision making, the need for exploration and clarification of available evidence ${ }^{[20]}$. At this stage students can determine the project or product that will be made to overcome the problems that arise based on the results of observations during the learning process that has been done.

This stage students and their groups with the guidance of teachers draw up a project creation schedule ranging from project planning to report making and project publication. The findings at this stage are the determination of the project schedule carried out by the teacher with the agreement and readiness of the students. This is done by considering the time, so that the learning process with the Problem-Project Based Learning model can be carried out as planned.

\subsubsection{Project assignments and presentations}

Student activities with their groups during project activities are recorded in the rubik of project creation activities. The findings in this stage are the cooperation of students with their groups in the process of making projects and discussions in bringing up ideas for the project to be made.Projects created by students contain creativity such as groups that create posters about solicitation to maintain the ecosystem environment around students created in a circular form that posters are usually made square. The creative product category is to the extent that the product is new (original) is very rare among the products made by students with the same experience and training, causing surprises (suprising) before giving the assessment of students even shocked and gave rise to the idea of other original products ${ }^{[21]}$. Here's an image of learning activities at the project and presentation task stage.

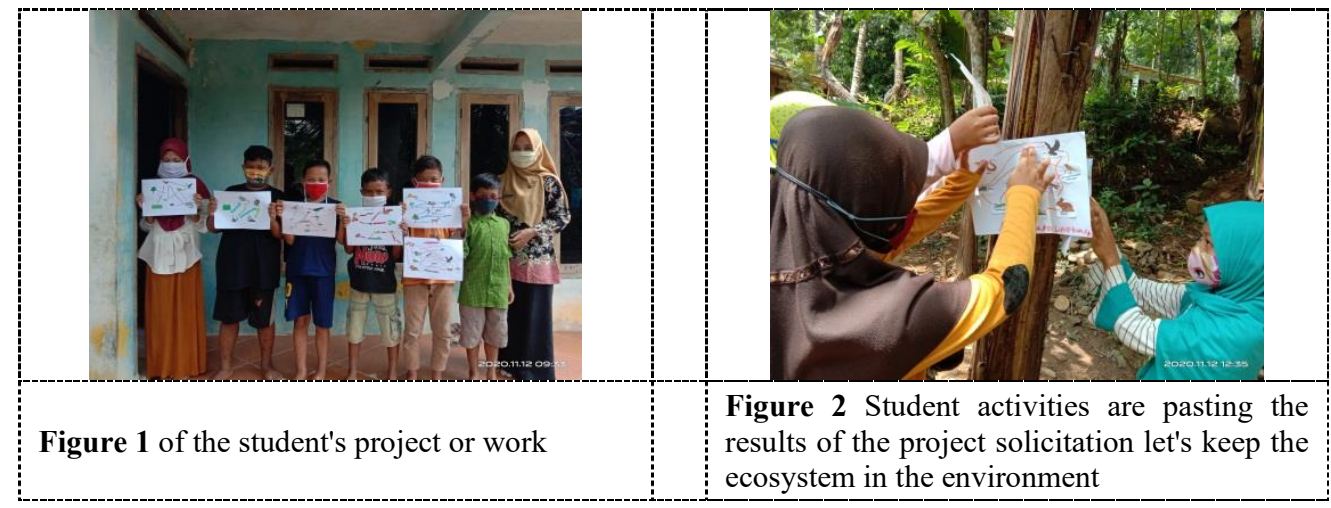

Entering the presentation activities, the findings at this stage are when the group presents the project made, there is a question and exchange of opinions in providing criticism and suggestions to the group presenting. The process of receiving criticism, input and suggestions makes the learning process Problem-Project Based Learning can facilitate the scientific attitude of students in receiving opinions or inputs from other students. The number of inputs in the form of ideas for the project presented by each group, indicates that the attitude of discovery and creativity of students has begun to form.Strategies that can be taken to improve children's creative thinking involve children in telling or presenting as many ideas as possible ${ }^{[22]}$. The findings were further after the group presented the benefits, advantages and disadvantages of the project being created, then each group carried out the action/demo.The 
action here is that students interact directly with the community towards the project being created, so that the resulting project can be utilized for the general public. When carrying out group actions that create posters to preserve and preserve the ecosystem, providing socialization to students and elderly students in the surrounding environment to maintain and preserve it.

The learning process implemented in the control group using the non Problem-Project Based Learning model was carried out at the same time and material as the experimental group for each meeting.The learning process carried out in the control group starts from students being assigned to read a discourse, make questions from reading results, conduct group discussions, conduct question and answer questions, teachers explain the subject matter and students do tasks, occasionally teachers conduct learning in the form of games while singing. The material given to the control group is the same as the material given to the experimental group for each meeting.The difference is that the control group of learning process takes place naturally as in their daily life. The learning model presented does not follow the syntax of the existing learning model or often changes according to the way the teacher is delivered.

Overall, based on the analysis above conducted on the implementation of learning with Problem-Project Based Learning and non Problem-Project Based Learning models on food chain materials, it can be concluded that every stage in Problem-Project Based Learning learning can facilitate scientific attitudes and mastery of the concept of grade $\mathrm{V}$ students in elementary school where the research is conducted.

\subsection{Differences in Student Scientific Attitude Improvement through Problem-Project Based Learning Model and Non Problem-Project Based Learning Model}

\subsubsection{Differences in Students' General Scientific Attitudes}

To see the difference in scientific attitude improvement between students who obtain learning with Problem-Project Based Learning and non Problem-Project Based Learning models, then the researchers gave pretest at the beginning of learning and posttest at the end of the learning process to two groups namely experimentation and control. The following table is presented showing the results of descriptive quantitative analysis in the form of the acquisition of average values of pretest and posttest, N-gain scientific attitude for two groups of experiments and controls, namely as follows:

Table 3 Description of the average value of scientific attitude pretest and posttest, N-gain for two groups of experiments and controls

\begin{tabular}{|c|c|c|c|c|c|c|c|c|c|}
\hline \multirow{2}{*}{ Group } & \multirow{2}{*}{$\mathrm{N}$} & \multicolumn{2}{|c|}{$\mathrm{A}$} & \multirow{2}{*}{$\begin{array}{c}\mathrm{N}- \\
\text { gain }\end{array}$} & \multirow{2}{*}{$\mathrm{SD}$} & \multirow{2}{*}{ Nor } & \multirow{2}{*}{ Hom } & \multirow{2}{*}{$\mathrm{Ta}$} & \multirow{2}{*}{ To } \\
\hline & & Pretest & Posttest & & & & & & \\
\hline Experiment & 17 & 50,14 & 70.66 & 0,41 & 0,02 & 0,101 & \multirow{2}{*}{0,53} & \multirow{2}{*}{4,051} & \multirow{2}{*}{2,110} \\
\hline Control & 17 & 46,47 & 66,47 & 0,37 & 0,08 & 0,824 & & & \\
\hline
\end{tabular}

Note: number of students (N), average (A), standard deviation (SD), normality (Nor), homogenity (Hom), Tcount (Ta), Ttable (To)

Level of signification in $\alpha=0.05$

Table 3 shows the posttest average values of both groups, the experimental group is superior to the control group. Significant differences can be seen in the 20,52 superior experiment group and the control group increased by 20 . Based on table 3.1 that it can be 
concluded that Ha is accepted, because Thitung's value is greater than Ttabel and is located in the Ho rejection area. So the research hypothesis there are differences that state that the improvement of students' scientific attitudes in the learning process using Problem-Project Based Learning and non Problem-Project Based Learning is acceptable.

\subsubsection{Differences in Student Scientific Attitudes Based on Indicators}

The N-gain calculation of each indicator of scientific attitude is based on data on the value of attitude scale processing obtained from the experimental group using Problem-Project Based Learning learning and the control group that got the learning with the non ProblemProject Based Learning model. The following table is presented showing the results of descriptive analysis in the form of average pretest and posttest values, standard deviation, and $\mathrm{N}$-gain in percent $(\%)$ for each indicator of scientific attitudes are as follows:

Table 4 Average standard deviation value, N-gain on scientific attitude indicators for two groups of experiments and controls

\begin{tabular}{|c|c|c|c|c|c|c|c|c|c|c|c|}
\hline \multirow{3}{*}{ No } & \multirow{3}{*}{ ISA } & \multicolumn{5}{|c|}{ Experimental Groups } & \multicolumn{5}{|c|}{ Control Groups } \\
\hline & & \multicolumn{2}{|c|}{ Pretest } & \multicolumn{2}{|c|}{ Posttest } & \multirow{2}{*}{$\mathrm{N}-\mathrm{G}$} & \multicolumn{2}{|c|}{ Pretest } & \multicolumn{2}{|c|}{ Posttest } & \multirow{2}{*}{$\mathrm{N}-\mathrm{G}$} \\
\hline & & A & $\mathrm{SD}$ & A & $\mathrm{SD}$ & & A & $\mathrm{SD}$ & A & $\mathrm{SD}$ & \\
\hline 1 & $\begin{array}{l}\text { Curious } \\
\text { attitudes }\end{array}$ & 53,4 & 7,47 & 77 & 15,4 & 49,6 & 47,3 & 10 & 53,5 & 19,4 & 11,7 \\
\hline 2 & $\begin{array}{l}\text { critical } \\
\text { attitudes }\end{array}$ & 50,5 & 9,66 & 71,1 & 12 & 41,6 & 44,1 & 15,1 & 48,5 & 18,3 & 7,89 \\
\hline 3 & $\begin{array}{l}\text { honest } \\
\text { attitudes } \\
\text { attitudes } \\
\text { of }\end{array}$ & 42,0 & 5,01 & 64,1 & 10,0 & 38,0 & 40 & 11,4 & 51,1 & 10,6 & 18,6 \\
\hline 4 & $\begin{array}{l}\text { discovery } \\
\text { and } \\
\text { creativity }\end{array}$ & 53,5 & 11,8 & 70,2 & 11,7 & 36,0 & 1,47 & 7,01 & 45,8 & 6,66 & 7,53 \\
\hline
\end{tabular}

Table 4 shows learning on the theme of 5 food chain material ecosystems in grade $\mathrm{V}$ elementary school, both the experiment group and the control group all resulted in a positive $\mathrm{N}$-gain average on all indicators of students' scientific attitudes. It can be proven that learning using Problem-Project Based Learning and non Problem-Project Based Learning can improve students' scientific attitudes. A significant difference was found in the experimental group that obtained an average $\mathrm{N}$-gain higher than the control group. The more detailed explanation of the findings of each indicator of scientific attitude can be explained as follows.

\subsubsection{Curiosity}

The findings in the curiosity indicator are the average $\mathrm{N}$-gain value of scientific attitudes for curious attitude indicators in the experimental group $(49,67 \%)$ moderate category, and control group $(11,73 \%)$ classified as low category. The $\mathrm{N}$-gain for the experimental group was better than the control group by a difference $(37,94 \%)$ It is said to be better because the experimental group that got the learning with Problem-Project Based Learning, especially the food chain material in grade V elementary school can facilitate the development of students' 
curiosity. The embodiment of this attitude is reflected in student activities in the first and second stages of the Problem-Project Based Learning model. Students are taught to make formulations and factors that cause problems related to the food chain. In addition to the knowledge gained in the first and second stages of Problem-Project Based Learning is also taught planting attitudes.

From the results of the analysis of students' grades on indicators of curiosity, obtained data of a number of students who got a score of 100 or all four statement items on the numbers 1 to 4 who got a score of 4 . At the time of posttest, the experiment and control group each numbered 3 students (18\%) but the average value of the experiment group was superior to the control group of 77,05 and 53,52 or a difference of 23,52 .

\subsubsection{Critical Thinking}

The findings in the critical thinking attitude indicators are the average $\mathrm{N}$-gain value of scientific attitudes for critical thinking attitude indicators in the experiment group 41,66 classified as medium category and control group 7,89 classified as low category. The N-gain for the experimental group was better than the control group with a difference of 33,77 . In the Problem-Project Based Learning model, learning facilitates students to develop critical thinking attitudes. This attitude is reflected when students do group work in completing projects to solve problems about the food chain around, in stages three and four.

From the data of the results of the score analysis on indicators of critical thinking attitudes of students, obtained data of students who got 100 for the experimental group of 7 students $(41 \%)$ and a control group of 4 students $(23 \%)$. The average posttest value of the experimental group was superior to the control group's 71,17 and 48,52 or a difference of 22,64 .

\subsubsection{Honest}

The findings in the honest indicator are the $\mathrm{N}$-gain value of scientific attitudes to honest indicators in the low category experimental group. In the experimental group $(38,07 \%)$ category and control group $(18,62 \%)$ classified as low category. A significant difference was found in the experimental group that obtained an average $\mathrm{N}$-gain higher than the control group. From the results of student grade analysis on honest indicators, data obtained the number of students who got a score of 100 for the experimental and control group of 5 students $(14 \%)$ the average value of the experiment group was superior to the control group of 64,11 and 51,17 or a difference of 12,94 .

The average posttest score of the honest attitude of the experimental group was superior to the control group because the students' initial understanding of the indicators already existed before the research process was conducted. This causes the learning model to be used both Problem-Project Based Learning and non Problem-Project Based Learning has no significant effect.

\subsubsection{Attitudes of discovery and creativity}

The findings in the attitude indicators of discovery and creativity are the average value of $\mathrm{N}$-gain scientific attitudes for indicators of attitudes of discovery and creativity in the experimental group $(36,07 \%)$ category and control group $(7,53 \%)$ classified as low category. The N-gain group was ahead of the control group by a margin $(28,53 \%)$. In the Problem- 
Project Based Learning model, learning facilitates students to develop attitudes of discovery and creativity, the attitude is reflected when students do group work in stages five and six. The expected attitude of the learning outcomes at this stage is to save the environment by creating projects to solve environmental problems and sort out organic and inorganic waste by conducting demonstrations on how to dispose of waste properly. The emergence of both attitudes is poured in the form of projects made by students, such as for garbage and saving the environment there are groups that make posters or ideas to invite students.

From the results of the analysis of student grades on indicators of attitudes of discovery and creativity, data obtained the number of students who got 100 for the experimental group of 10 students $(58 \%)$ and a control group of 2 students $(12 \%)$. The average score of the experimental group was superior to the control group at 70,29 and 45,88 or a difference of 24,41 .

\subsection{Differences in Improving Student Concept Mastery through Problem-Project Based Learning and Non Problem-Project Based Learning Models}

\subsubsection{Differences in the Student Concept Mastery in General}

To see the difference in concept mastery between students who obtained learning with Problem-Project Based Learning and non Problem-Project Based Learning models, the researchers gave pretests at the beginning of learning and posttest at the end of the learning process for two experimental and control groups. The following table is presented showing the results of descriptive quantitative analysis in the form of pretest and posttest average values, $\mathrm{N}$-gain mastery of concepts for two groups of experiments and controls are as follows:

Table 5 Description of average value of pretest, posttest, $\mathrm{N}$-gain mastery concept for two groups of experiments and controls

\begin{tabular}{cccccccccc}
\hline \multirow{2}{*}{ Group } & \multirow{2}{*}{$\mathrm{N}$} & \multicolumn{2}{c}{$\mathrm{A}$} & $\mathrm{N}-$ & \multirow{2}{*}{$\mathrm{SD}$} & Nor & Hom & \multirow{2}{*}{ Ta } & \multirow{2}{*}{ To } \\
\cline { 3 - 6 } & & Pretest & Posttest & gain & & & & & \\
Experiment & 17 & 47,5 & 64,85 & 0,32 & 0,14 & 0,103 & \multirow{2}{*}{0,491} & \multirow{2}{*}{3,059} & 2,110 \\
Control & 17 & 52,5 & 61,91 & 0,19 & 0,11 & 0,868 & & \\
\hline
\end{tabular}

Note: number of students (N), average (A), standard deviation (SD), normality (Nor), homogenity (Hom), Tcount (Ta), Ttable (To)

Significance level at $\alpha=0.05$

Table 5 shows the average posttest results of the experimental group is superior to that of the control group. Significant differences were found in the superior experiment group 17,4 and the control group up 9,41. The distribution of values in the experimental group was more evenly distributed than the control group. This can be seen from the standard value of N-gain deviation for the experimental group superior to the control group. Based on table 3.3 it can be concluded that Ha is accepted, because thitung value is greater than Tttabel and located in Ho rejection area. So the research hypothesis that states there are differences in mastery of the concept of students learning with Problem-Project Based Learning and non Problem-Project Based Learning is acceptable.

The low average value of $\mathrm{N}$-gain mastery of concepts in this study is due; first, at the time of the implementation of the concept mastery test, the condition of the students in the houses next to it is less conducive, so it affects the students who are doing the test in the room. 
This condition also makes the result of obtaining value during the pretest between the experimental group and the control is not maximal. Activities to encourage children's creativity as a whole, one of which is that children need to feel comfortable and stimulated in the classroom ${ }^{[21]}$. Second, from the results of analysis during the pretest activities, and interviews with teachers and student representatives, it was obtained that the students of both classes were not used to working on the concept mastery. Especially the questions in the form of descriptions that issue high thought processes, so that the average student's answer is not in accordance with the commands in the question. So far, students have been given questions based on the questions contained in the student handbook in the form of multiple choice and short stuffing. Students still have difficulty in answering questions in the form of description kaerena answers students are still a form of short answers, not elaborated. If the student has become accustomed to solving the problem of the form of the story, then it will automatically know what is known and what is asked of each question, according to his habits ${ }^{[23]}$.

Third, if reviewed from the level of completion, where learning is said to be complete if the student has mastered $65 \%$ of the material, then the level of completion of learning for mastery of the concept of the posttest results of the experimental group is $64,85 \%$ (category not yet completed) and for the control group $61,91 \%$ (category not yet completed). When viewed from the level of individual completeness achieved by both groups, the data obtained by students who mastered the material $65 \%$ and above there were 5 students for the experiment group and 1 student for the control group. The data can be seen in the attachment. From the data, in general, the completion of concept mastery for experimental groups and control groups can be said to be incomplete. Fourth, the learning done before the research is only learning that follows the stages in the material in the textbook online. Learning is more verbal and assigning tasks during the coronavirus pandemic. This condition also makes it difficult for students to understand the lesson and not able to connect the concept with the other concept or the student has not been able to connect the subject matter with the situation of daily life.

\subsubsection{Differences in in Concept Mastery Based on Cognitive Domain}

The difference in $\mathrm{N}$-gain is each realm of cognitive mastery of concepts. The following table is presented showing the results of descriptive quantitative analysis in the form of average pretest and posttest values, standard deviation, and average $\mathrm{N}$-gain in percent $(\%)$ for each realm of cogtive mastery of concepts, namely as follows:

Table 6 Value, standard deviation, N-gain in the cognitive realm of concept mastery for two groups of experiments and control

\begin{tabular}{|c|c|c|c|c|c|c|c|c|c|c|c|}
\hline \multirow{3}{*}{ No } & \multirow{3}{*}{ MCI } & \multicolumn{5}{|c|}{ Experimental Groups } & \multicolumn{5}{|c|}{ Control Groupss } \\
\hline & & \multicolumn{2}{|c|}{ Pretest } & \multicolumn{2}{|c|}{ Posttest } & \multirow{2}{*}{$\mathrm{N}-\mathrm{G}$} & \multicolumn{2}{|c|}{ Pretest } & \multicolumn{2}{|c|}{ Posttest } & \multirow{2}{*}{$\mathrm{N}-\mathrm{G}$} \\
\hline & & A & SD & A & SD & & A & SD & A & SD & \\
\hline 1 & $\mathrm{C} 1$ & 47,05 & 8,48 & 64,71 & 15,62 & 33,33 & 47,06 & 8,48 & 62,35 & 15,62 & 28,88 \\
\hline 2 & C2 & 45,88 & 9,39 & 67,65 & 12,51 & 40,21 & 58,24 & 13,8 & 65,88 & 21,52 & 18,30 \\
\hline 3 & $\mathrm{C} 3$ & 47,05 & 7,85 & 61,76 & 9,35 & 27,77 & 46 & 7,07 & 48,82 & 8,57 & 5,22 \\
\hline 4 & $\mathrm{C} 4$ & 53,52 & 7,85 & 65,82 & 21,35 & 26,45 & 54,71 & 6,24 & 62,35 & 14,78 & 16,88 \\
\hline
\end{tabular}

Note: number (No), mastery of concept indicator (MCI ), average (A), standard deviation

(SD), N-Gain \% (N-G), remember (C1), understand (C2), apply (C3), analyze (C4) 
Table 6 shows that both the experimental group and the control group all produced positive $\mathrm{N}$-gain averages in all cognitive realms of concept mastery. This can prove that learning using Problem-Project Based Learning and non-Problem-Project Based Learning models can improve concept mastery. A significant difference was found in the experimental group that obtained an average $\mathrm{N}$-gain higher than the control group. The more detailed explanation of the findings of each cognitive realm of concept mastery can be explored as follows:

\subsubsection{C1 (remember)}

The findings in the cognitive real of $\mathrm{C} 1$ were average $\mathrm{N}$-gain mastery of the concept of cognitive domain $\mathrm{C} 1$ in the experimental group $33,33 \%$ classified as a moderate category with a posttest average score of 64,71 and a control group of $28,88 \%$ relatively low with a posttest value of 62,35 . The low $\mathrm{N}$-gain score for the cognitive sphere of $\mathrm{C} 1$, from the results of the analysis of students' answers for both groups at the time of pretest, in answering what the ecosystem meant is still incomplete. Students answer questions such as; a system, a reciprocal relationship. At the time of mentioning the example, the student's answer at the pretest time was like; ecosystems, rice field ecosystems, river ecosystems, pond ecosystems. Whereas the expected answer is to mention more than two examples

The N-gain results of cognitive sphere $\mathrm{C} 1$ for the experimental group that gained learning with Problem-Project Based Learning were better than the control group that got non Problem-Project Based Learning learning. In the Problem-Project Based Learning model, teachers play a role in facilitating students to express many ideas, train to ask questions or formulate problems and mention examples based on video impressions and explanations from teachers. Meanwhile, in the control group that got the learning with non Problem-Project Based Learning model, the teacher provided the learning by assigning students to read the reading text and then answer questions about the text. Students are less involved in the process of being discussed, asked questions and trained in formulating problems based on the text read. The same thing in project-based learning is the essential question (start with the essential question $)^{[24]}$. In this stage the teacher motivates students to be able to ask questions related to the topic, and can direct the student's questions to more specific things.

The next finding of the cognitive sphere of $\mathrm{C} 1$ is from interviews with class teachers and student representatives, to find out the difficulty of students in answering questions number one and two (C1). It is obtained that the low cognitive sphere of $\mathrm{C} 1$ is caused because students are rarely given the opportunity to ask questions or are less trained in introducing ecosystems in the surrounding environment. In fact, one of the characteristics of students who have good memory is often asking good questions. So far, questions are only submitted by teachers and students to answer questions given by teachers through online media. Students are less involved in active learning situations that encourage students to bring their experiences, ideas, interests, and materials to every meeting offline or online. This is not in accordance with the teaching philosophy that encourages the cognitive ability of $\mathrm{C} 1$ i.e. the child should be an active student. They need to be encouraged to bring their experiences, ideas, interests and materials to every meeting offline or online. It is possible for them to discuss together with the teacher about the purpose of working/learning each meeting, and need to be given autonomy in determining how to achieve it. 


\subsubsection{2. $\quad$ C2 (understand)}

The findings in the cognitive realm of $\mathrm{C} 2$ were the average $\mathrm{N}$-gain mastery of student concepts for the cognitive sphere of $\mathrm{C} 2$ in the experimental group of $40,21 \%$ classified as a moderate category with a posttest average score of 67,65 and the control group of $18,30 \%$ classified as low category with a posttest average score of 65,88 . The low $\mathrm{N}$-gain value for the cognitive sphere of $\mathrm{C} 2$ is caused by students having difficulty when students are assigned to mention the components of the ecosystem as well as in the processes that occur within the ecosystem based on the understanding associated with the situation of residence. The average answer to questions 3 and 4 has similarities in mentioning components and the answers are short without being described. Students just answer like; abiotic components and biotic components.

The $\mathrm{N}$-gain results of cognitive sphere $\mathrm{C} 2$ for the experimental group who got learning with Problem-Project Based Learning were better than the control group that got non ProblemProject Based Learning learning. In the Problem-Project Based Learning model, teachers facilitate students to discussion with their groups in understanding an idea/gasan related to the ecosystem in the surrounding environment. Meanwhile, in the control group that got the learning with non Problem-Project Based Learning model, ideas in understanding the ecosystem are generally conclusions based on the text read. The role of students is more on listening to the teacher's explanation in understanding the idea or way of solving a problem. The learning conditions in the experimental group are in accordance with the principles of project-based learning, which involves real-life tasks to enrich learning ${ }^{[25]}$.

\subsubsection{C3 (apply)}

The findings in the cognitive sphere applying the average $\mathrm{N}$-gain value of student concept mastery for the cognitive sphere of $\mathrm{C} 3$ both groups got a low category. In the experimental group $27,77 \%$ were classified as low with a posttest average score of 61,76 and the control group 5,22\% classified as low category with a posttest average score of 48,82 . The cause of the low $\mathrm{N}$-gain score for the cognitive sphere of $\mathrm{C} 3$, from the results of interviews conducted to student representatives of both groups (experiments and controls). Students have difficulty explaining a problem and its relevance to other communities. The difficulty experienced by students is one of the factors, namely the lack of availability of resources to support the learning process.

Existing learning resources, such as student worksheets, printed media and some sources from the internet are less utilized by students. In addition, the learning time is limited, so the opportunity for students to try ideas becomes less maximal. Direct student involvement in the learning process is limited to discussion and question and answer. Students are rarely given the opportunity to explore more with experimental tools and materials. To be able to develop or apply student ideas, teachers should encourage students to come up with creative ideas in solving a problem by using existing learning resources and provide opportunities for students to explore more with experimental tools and materials ${ }^{[26]}$.

\subsubsection{C4 (analyze)}


The findings in the cognitive realm of $\mathrm{C} 4$ are that the average $\mathrm{N}$-gain value of mastery of student concepts for the cognitive sphere of $\mathrm{C} 4$ both groups got a low category. In the experiment group $26,45 \%$ were classified as low category with a posttest score of 65,82 and the control group $16,88 \%$ classified as low category with a posttest average value of 62,35 . The N-gain for the experimental group was better than the control group with a difference of $9,57 \%$. It is said to be better because the experimental group, which obtains learning with the Problem-Project Based Learning model, facilitates students in the cognitive sphere of $\mathrm{C} 4$ at the stage of self-learning through investigation. At this stage, students through their groups together plan the ecosystem in the neighborhood around the residence.

Low $\mathrm{N}$-gain indicators in the cognitive sphere of $\mathrm{C} 4$, the results of analysis of data from answers in students were assigned to answer number 8 based on the type of food, describe various animals and beikan examples. Students for both groups answered on average such as; Cows eat grass, lions eat meat. Students still have difficulty analyzing the names of the types of plant-eating animals, meat and eaters of everything.

To be able to understand more of the cognitive realm of $\mathrm{C} 4$, the authors conducted a live interview with students to get clarity on the answers given. Data from the researchers' interviews found answers that students responded based on their imagination, or student mindset, but when asked for examples of omnivorous animals students were still at a loss to explain.

\section{Conclusion}

Every stage in the implementation of Problem-Project Based Learning can facilitate scientific attitude and mastery of the concept of grade $\mathrm{V}$ students in elementary school where research. The students' scientific attitudes arise when conducting observations directly in the environment around which students live related to the ecosystem. The results of these observations are followed up and sought to solve the problem in the form of project creation and take real action, namely socializing in general. An example of ilmah attitude as a result of Problem Project Based Learning is the agreement between students and teachers to equally maintain the environment and not litter. Mastery of the concept of students arises when conveying many ideas in formulating problems, making the project related to the act of preserving the environment. An example of the product of mastery of the concept produced by students is a poster containing a call to preserve the ecosystem in the form of a circle that is generally a square-shaped poster.

There are differences in scientific attitudes between students who obtain learning with Problem-Project Based Learning and non Problem-Project Based Learning models. ProblemProject Based Learning model improves scientific attitude compared to non Problem-Project Based Learning model. This can be seen from the average $\mathrm{N}$-gain for the experimental group of 0,41 or $41 \%$ and the control group of 0,37 or $37 \%$.

There are differences in concept mastery between students who obtain learning with Problem-Project Based Learning and non Problem-Project Based Learning models. ProblemProject Based Learning model improves concept mastery compared to non Problem-Project Based Learning model. This can be seen from the average $\mathrm{N}$-gain for the experimental group of 0,32 or $32 \%$ and the control group of 0,19 or $19 \%$.

\section{References}


[1] Anderson L W \& Krathowhl D R 2010 Kerangka Landasan Untuk Pembelajaran, Pengajaran dan Asesmen: Revisi Taksonomi Pendidikan Bloom. Terjemahan. Agung Prihantoro (Yogyakarta: Pustaka Pelajar)

[2] Marlina Sugeng U \& Lia Y 2017 Pengaruh Authentic Problem Based Learning (aPBL) terhadap Penguasaan Konsep Siswa Kelas IV Sekolah Dasar J Pendidikan: Teori, Penelitian, dan Pengembangan 2 p.1509-1514.

[3] Nisrina N Gunawan G \& Harjono A 2016 Pembelajaran kooperatif dengan media virtual untuk peningkatan penguasaan konsep fluida statis siswa J Pendidikan Fisika dan Teknologi 2 P.66-72.

[4] Susanto A 2014 Teori belajar \& pembelajaran di Sekolah Dasar (Jakarta: Kencana)

[5] George R 2003 Growth in Students' Attitudes about the Utility of Science over the Middle and High School Years: Evidence from the Longitudinal Study of American Youth $J$ of Science Education and Technology 12 p. 439-448

[6] Fakhrudin 2010 Sikap Ilmiah Siswa dalam Pembelajaran Fisika dengan penggunaan Media Komputer Melalui Model Kooperatif Tipe Stad pada Siswa Kelas X3 SMA Negeri I Bangkinang Barat J Geliga Sains 4 p.18-22

[7] Solihin dan Widayani H 2016 Sikap Ilmiah Peserta Didik dalam Pembelajaran Fisika dengan Metode Accelerated Learning Type Master di Kelas X-TKR-2 SMK Negeri 1 Muaro Jambi $J$ Edufisika 1 p.21-24

[8] Harlen W 1992 The Teaching of Science: Studies in Primary Education (London: David Fulton Publishers)

[9] Ruhimat Toto 2009 Pengembangan Pembelajaran Siswa Aktif (Active Learning). [Online] tersedia di:http//www.repository.upi.edu [12 Desember 2020]

[10] Purwandari R D 2014 Pengaruh Model Pembelajaran Problem-Project Based Learning terhadap Jiwa Wirausaha Siswa SMK melalui Produksi Eksterior $J$ Sainteks XI

[11] Sugiyono 2016 Metode Penelitian Pendidikan (pendekatan Kuantitatif, Kualitatif, dan R\&D) (Bandung: Alfabeta)

[12] Creswell J W 2014 Research Design (Yogyakarta: Pustaka Belajar)

[13] Widodo A 2007 Buku Panduan Pendidikan Ilmu Pengetahuan Alam (Pusat Perbukuan. Depdiknas)

[14] Rudi Susilana dan Capi Riyana 2009 Media Pembelajaran (Bandung: CV Wahana Prima)

[15] Harsiti T 2012 Kajian Kritis Terhadap Penerapan Bahan Ajar Aflaton sebagai Bahan Ajar Pendidikan Karakter di Sekolah Dasar J Sekolah Dasar 21 p.151-73

[16] Aziz S 2014 Peningkatan Keterampilan Sains dan Keterampilan Berfikir Kritis melalui Pembelajaran Berbasis Proyek (Tesis SPs UPI Bandung: Tidak dipublikasikan)

[17] Yusuf S 2012 Psikologi Perkembangan Anak dan Remaja (Bandung: Remaja Rosdakarya)

[18] Samsudin U 2009 Penerapan Pembelajaran Berbasis Masalah untuk Meningkatkan Pemahaman Konsep dan Keterampilan Proses Sains Siswa Kelas VI SD pada topik Energi Listrik (Tesis SPs UPI Bandung: Tidak dipublikasikan)

[19] Suryati 2012 Efektifitas Model Pembelajaran Multi-Siklus Deal untuk Mengajarkan Keterampilan Pengembilan Keputusan Siswa Sekolah Dasar J Sekolah Dasar 21 p.1-8

[20] Suryani T 2012 Pengaruh Proses Belajar melalui Inkuiri Sosial terhadap Pemahaman Konsep dan Internalisasi Nilai Peduli Lingkungan dalam Pembelajaran IPS (Tesis SPs UPI Bandung. Tidak dipublikasikan)

[21] Munandar U 2009 Pengembangan Kreativitas Anak Berbakat (Jakarta: PT Reneka Cipta)

[22] Santrock J H 2011 Life-Span Development; Perkembangan Masa Hidup (Edisi Ketigabelas, jilid 1) Penerjemah: Widyasinta B (Jakarta: Erlangga)

[23] Sarjiman 2014 Pembelajaran Soal Matematika Bentuk Cerita dengan Pendekatan Pemecahan Masalah pada Siswa SD (Yogyakarta: Staff Site UNY)

[24] Sari D Y 2014 Memperkuat Upaya Pengembangan Karakter Kemandirian Isiswa melalui Project Based Learning (Tesis SPs UPI Bandung: Tidak dipublikasikan)

[25] Hosnan M 2014 Pendekatan Saintifik dan Kontekstual dalam Pembelajaran Abad 21 (Bogor: Ghalia Indonesia) 
[26] Fauziah 2011 Analisis Kemampuan Guru dalam Mengembangkan Keterampilan Berpikir Kreatif Siswa SD Kelas V pada Pembelajaran IPA (Tesis SPs UPI Bandung: Tidak dipublikasikan) 